\title{
BİR SOSYALLEŞME ARACI OLARAK YENİ MEDYA
}

\author{
Alper Altunay*
}

\section{ÖZET}

Yeni medya 2000'li yillarm en moda kavramlarmdan biridir. Gerek doğrudan medya üzerine yapılan çalışmalarda, gerekse dolaylı olarak medya ile ilişkilendirilmiş araştırmalarda yeni medyanın karakteristik özellikleri farklı şekillerde sınanmaya çalışılmış, yeni medya tanımlarının sinırları sürekli yeniden yapılandırılır olmuştur. 2000'li yılların toplumsallaşma süreci, modern dünyanın geleneksel medyasının ortaya çıkardığı toplumsallaşma yapısindan önemli farklılıklar içerir. Kavram olarak ă̆ toplumu, Castells (2008) tarafından tanımlanmış, gündelik yaşamlarında geleneksel iletişim araçları yerine yeni medyayı kullanagelen, yeni medyanın iletişim olanaklarını gündelik yaşamı içine yerleştirmiş ve belirli bir alışkanlık edinmiş bir topluma karşılık gelmektedir. A $\breve{g}$ toplumu, Bell'in (1996) endüstrisi sonrası toplumunun toplumsal yapılanmasını ă̆ üzerinden gerçekleştiren biçimi olarak tanımlanabilir. Toplumsal yapılanmasını da bilginin serbest dolaşımı üzerine şekillendirir. Tıpkı endüstri toplumunda üretilen ürünlerin serbest dolaşımında olduğu gibi, ă̆ toplumunda öne çıkan en önemli olgu, önemli ya da önemsiz, anlık ya da geçmiş, üretilen tüm bilgilerin paylaşılabilir, manipüle edilebilir olmasıdır. $B u$ araştırma, ă̆ toplumunun yapılanmasında, toplumsallaşmasında yeni medyanın ne gibi etkilerinin olduğunu; var olan toplumsal yapıyı şekillendirmesinde hangi özelliklerinden yararlandığını ortaya koymayı amaçlamıştır. Bu amaç doğrultusunda yeni medyanın karakteristik özellikleri özetlenerek, toplumsallaşma ile olan kavramsal ilişkileri ortaya konmaya çalışılmıştır. Farklı toplumsallaşma düzeylerinde yeni medyanın hangi karakteristik özellikleri ile işlev gördü̈̆̈̈, 2000'li yıların ă̆ toplumunun yapılanmasında hangi yönlerinin öne çıktı̆̆ğ, literatür taraması ışı̆̆ında betimlenmiştir.

Anahtar Kelimeler: Yeni medya, sosyal ă̆lar, toplumsallaşma

\section{NEW MEDIA AS A SOCIALIZATION TOOL}

\begin{abstract}
New media is one of the most in vogue concepts of $21^{\text {st }}$ century. New media's characteristics have been tested in various methods and its definitions have been reconstructed through studies that were directly or indirectly about media. The borders of the definitions of the new media were reconstructed consistently. The socialization process of the $21^{\text {st }}$ century network society differs significantly from the socialization structure associated with the traditional media of the modern world. The concept of network society was defined by Castells (2008) as a society that uses new media in daily life instead of traditional forms of communication, which has embedded the communication possibilities of new media to everyday life and has developed a certain habit. Network society can also be defined as a form of Bell's (1996) post-industrial society which realizes its social structur-
\end{abstract}

* Doç. Dr., Anadolu Üniversitesi İletişim Bilimleri Fakültesi 
ing through a network. While Bell signifies the generation and circulation of knowledge in his definition of the post-industrial society; in Castell's network society the social structuring processes and the circulation of knowledge is achieved over the network. For this reason, network society is an information society rather than an industrial one. It shapes its social structure around the free circulation of knowledge. Just like the free movement of the post-industrial society products, the most prominent phenomena of the network society is that any information can be distributed and manipulated regardless of significance or time of relevance. This study aims to determine the effects of new media in the structuring and social shaping of the network society, and to determine which of its qualities are utilized in shaping social structure. In accordance with this goal, the characteristics of new media have been summarized and the conceptual relationships between these characteristics and social structuring are portrayed. The determination of which characteristics of new media are functional in different levels of social structure and the aspects of which stand out in the structuring of the network society of the 2000s is portrayed through the literature review.

Keywords: New media, social networks, socialization

\section{Gíriş}

Yeni medya kavramı, son yıllarda birçok kuramcı tarafından farklı şekillerde ve farklı biçimlerde kullanılagelmiştir. Manovich (2002) yeni medyayı 2000'li yıllarin sayısal teknolojileri ile tanımlarken, Gitelman ve Pingree (2003) ise 1740-1915 arasında geliştirilen iletişim teknolojilerini yeni medya kavramı içinde ele alır. Oysa bu kavramı ortaya koyarken yanıtlanması gereken en önemli konu, neyin yeni olduğu değil, aracın hangi özelliklerinin yeni olarak tanımlandığıdır. Çünkü yeni ya da eski arasında yapılabilecek tüm göndermeler, belirli bir zaman sonra geçerliliğini yitirecek, daha sonra üretilen her ardıl iletişim teknolojileri bir öncekini eskiteceği için, yeni olma sıfatını kaybedecektir. "Yeni" kavramı sabit ve kalıcı bir tanım içermediği için, her geçen yıl geliştirilen her teknoloji bir eskisine göre yenidir. Oysa günümüz medyasının bir tanımlayıcısı olarak yeni medya kavramı sadece eski ile yeni arasındaki farkı ortaya koymakla kalmaz, aynı zamanda geleneksel medya ile arasında yapılanan farklılıkları, daha önce olmayan toplumsal kullanım biçimlerini ve bu kullanım biçimlerinden ortaya çıan yeni toplum-medya ilişkisini ifade eder. Bu makalenin amacı ise, geleneksel medyadan farklı olarak yeni medyanın ortaya çıkardığı yeni toplum-medya ilişkilerini açıklayabilmektir. Özellikle yeni medyanın en işlevsel ortamlarından biri olan sosyal ağların, toplumsallaşma süreçlerindeki yeri ve önemi problem edilmiş, bu doğrultuda gerçekleştirilen kaynak taraması ışığında; çözümlemeler geliştirilmiştir. Bu süreç doğrultusunda; yeni medyanın kavramsal olarak yerleştiği konum, tanımsal özellikleri ve toplumsallaşma süreçlerinde yeni medyanın rolü üzerine, temel kuramcıların kuramları eşliğinde bir literatür çalışması yapılmaya çalışılmiştır. 
Bu nedenle, yapılan çalışma; son yıllarda sosyal ağların gündelik yaşamdaki yerinin hızla arttığı bir dönemde, bu yeni iletişim ortamlarının var olan toplumsallaşma süreçlerine ne gibi farklılıklar getirdiğini ortaya koymakla sınırlıdır.

\section{KAVRAM OLARAK YENI MEDYA}

Yeni medya kavramı iletişim kuramları tarihi içinde defalarca kullanılagelmiştir. Her yeni teknoloji, sadece ortaya çıkardığı yeni teknik olanaklardan dolayı değil, bu yeni teknik olanakların sağladığı yeni iletişim süreçleri ve yeni iletişim kültürü nedeniyle de "yeni medya kavramı ile anılır olmuştur. Yeni, eski ile olan bir karşılaştırma, eski ile sonradan geliştirilen arasındaki farklılık ve bu farklılıkların toplumsal kullanım süreçleri içinde tanımlanır. Beville (1948) televizyon, radyo ve faksimile gibi iletişim ortamların birer yeri medya olarak tanımlandığında tarih 1948 yılıdır. Marvin (1988), elektrik ve elektronik teknolojisinin yeni kullanım alanlarını ifade ederken yine benzer bir ifadeyi kullanır; oysa 2000'li yıllara kadar yeni olma durumu birçok iletişim teknolojisi için defalarca kullanılmış ve bir o kadar daha kullanılmaya adaydır. Her yeni iletişim teknolojisinin bir öncekine göre yeni olarak tanımlanması bu nedenle oldukça sıklıkla görülen bir tanımlama biçimidir.

Tarihsel süreç içerisinde yaşanan bu "yenilenme" aşamaları, teknolojik belirleyici bir yaklaşım içinde çözümlenmeye başlasa da, bu ve benzer gelişimlerin sadece teknoloji üzerinden açıklamaya çalışmak yetersiz kalabilir. Nihayetinde tüm bu iletişim araçlarının hepsi belirli bir iletinin belirli bir araç sayesinde aracılanması sürecini yerine getirirler. Aracılanmış iletişim (mediated communication) belirli bir iletinin, alıcısına belirli bir araç ya da ortam sayesinde iletilmesi sürecini tanimlar (Pavlik and McIntosh 2004: 70). Alemdar ve Erdoğan (2005) bu tür arac1lama yöntemlerinin kullanılan teknoloji üzerinden, iletişim ortamlarının tanımlanmasına da yok açtı̆̆ını vurgular. Fotoğraf, film, sinema, radyo vb. İletişim ortamları aynı zamanda birer aracılama yöntemleri olarak kabul edilir. O halde yeni medya ile toplumsallaşma süreçlerinde, yeni medyanın ne tür aracılama yöntemleri kullandığı sorusu öne çıkar. Bir başka deyişle, yeni medyanın hangi karakteristik özelliklerinin, sosyalleşme süreçlerinde ne gibi rol oynayabileceği sorusu akla gelir. Bu sorunun yanıtı için de öncelikle yeni medyanın kendine özgü karakteristik yapısını özetleyebilmek, geleneksel medya ile olan farklılıklarını konumlandırabilmek önem taşır.

Yeni medya kavramını geleneksel medyadan ayırırken öne çıkan kavramlar sayısallık, taşınabilirlik, eşzamansızlık, etkileşimlilik, kitlesizleştirme, kişiselleştirebilme ve yöndeşme kavramları içinde sınıflandırılabilir (Altunay 2013). Bu sınıflandırma dışında farklı kuramcıların sayılan kavramlardan bazılarını öne çıkardığı ve diğerlerinden daha ayrıcalıklı bir konumda tartıştığı görülebilir. Bunun nedeni ise yeni medyanın henüz toplumsal yapı içinde geleneksel medya kadar yerleşmiş bir yapılanma içinde yer almaması, buna karşılık kuramcıların ise yeni medya-toplum arasındaki yeni ilişki biçimlerini sınıflandırmada bu tanımları 
yeniden gözden geçirme ihtiyaçları olabilir. Yine de tüm sınıflandırmalar yeni medya ve toplum arasında oluşan yeni yapılanmayı anlamada, kavramada bir çok kişiye önemli ipuçları vermektedir. Özellikle disiplinlerarası çalışmalarda bu sınıflandırmalardan bazılarının öne çıkması da kaçınılmazdır.

Öte yandan, yeni medya üzerine ilk kuramsal çalışmaları yapan Manovich, diğer yeni medya nitelemelerinden çok daha farklı bir sınıflandırma oluşturur ve kendi tanımları içinde erken dönem yeni medya araçları ifadesini ilk kez kullanarak, yeni medyanın tarihsel dönüşümüne de atıf yapar. Manovich (2003: 13-25), yeni medyanın genel özelliklerini özetlerken aşağıdaki ana başlıklar altında sıralar:

1. Siberkültüre karşı yeni medya - Siberkültür, internet ve ağ iletişimi (bloglar, çevrimiçi çoklu oyunculu oyunlar) ile ilişkili çeşitli toplumsal sosyal olgulara karşılık gelirken, yeni medya ise daha çok kültürel nesneler ve paradigmalar (sayısal ve analog televizyon, iPhone'lar) ile ilişkilidir. Bu noktada, yeni medya sadece aracın ürettiği kültür üzerine değil, aracın kullanım pratiklerini de kapsayan bir bakış açısı ile ele alınır. Sadece kültürel bir yaklaşımı değil, sosyo-ekonomik ve tekno-politik yaklaşımları da kapsar. Siberkültür daha çok çevrimiçi toplumsal yapılanmalar ve kültürel dönüşümler üzerine eğilirken, yeni medya kavramı, siberkültürün kapsamadığı tüm sayısal teknolojilerin ürettiği kültürel ve toplumsal dönüşümü inceler.

2. Bir Dağıtım Platformu Gibi Kullanılan Bilgisayar Teknolojileri Olarak Yeni Medya Manovich, yeni medya kavramını dağıtım ve sunum için (İnternet, Web siteleri, çoklu ortam, Blu-Ray diskler gibi) sayısal bilgisayar teknolojileri kullanan kültürel nesneler üzerinden tanımlar ve bunlara karşılık olarak konunun anlaşılması için neyin yeni medya olmadığını ise, televizyon, film, dergiler vb geleneksel iletişim ortamları ile örnekler. Bu tanımından sonra yeni medyanın etkileşimli sayısal teknolojiler üzerinden ifade edilir olması ile birlikte, yeni medya kavramındaki tartışmalar da sonlamıştır. Zaten bu tanımla birlikte, birkaç yılda bir tanımının yenilenmesinin gerektiği, kültürel ürünlerin bilgisayarlar ve dijital ortamlar üzerinden dağıtımı gerçekleştirildikçe; artık 'yeni medya' terimi 'yeni' olarak kalamayacağı da vurgulanmıştır. Yeni medya kavramındaki yeni, eski kavramı üzerine değil, geleneksel medya kavramı üzerine yapılandırılmıştır. Kavram yeni ile eskinin bir ayırımı üzerine değil, etkileşimli, çevrimiçi sayısal teknolojiler ile, etkileşimiz çevrimdışı teknolojiler üzerine oturmuştur.

3. Yazılımlar Tarafindan Kontrol Edilen Sayısal Veri Olarak Yeni Medya - Yeni Medya'nın dili, sayısal temsile ve bilgisayar tabanlı aktarıma dayanan tüm kültürel nesnelerin bazı ortak nitelikler paylaştığı varsayımı üzerine kurulmuştur. Burada yeni medyanın ortak özellikleri arasında nümerik temsil sistemi, modüler olabilme, otomasyon, değişkenlik ve kod çevrimi gibi daha teknik ifadeleri de kullanmak olasıdır; ancak burada her bilgisayar tabanlı kültürel üretimin bir yeni medya ürünü olmasından çok, yeni medya ürününün gitgide bilgisayarlaştırdığ1 kültürel durumlardan söz edilebilir. Manovich'in yeni medyanın temel öğelerin- 
den biri olarak tanımladığı yazılım tabanlı iletişimin günümüz karşılığımdaki ifadesi ise yöndeşme kavramına karşılık gelebilir. Yöndeşme yeni medyanın en temel özelliklerinden biri olarak, yazılım tabanlı bir çalışma prensibiyle yeni medya içeriklerini her aygıt için elverişli hale getirilmesi, gerektiğinde manipüle edilebilmesini de içerir.

4. Var olan Kültürel Gelenekler ile Yazılım Geleneklerin Bir Karışımı Olarak Yeni Medya - Günümüzdeki 'Yeni Medya' veri sunumu, erişimi ve müdahalesi için olan eski kültürel gelenekler ile bunların yeni geleneklerin bir karışımı olarak anlaşılabilir. 'Eski' veriler görsel gerçekliğin ve insan deneyiminin temsilleri olup 'yeni' veriler sayısal verilerdir. Bilgisayar, kilit 'yaratıcı' kararların dişında tutulmaktadır ve bir 'tekniker' konumuna yerleştirilmektedir. Örneğin, sinemada yapımın bazı alanlarında yazılım kullanılırken başka alanlarında bilgisayar animasyonları ile yaratılmaktadır. Öte yandan bilgisayar oyunları ise, kendi geleneklerini oluşturan nadir kültürel öğelerden biridir. Var olan kültürel gelenekler ile yazılım geleneklerini birleştiği yerde ise erken dönem yeni iletişim ortamları yer alır. Yeni medya var olan görsel kültürel gelenekler olan, farklı resmetme tekniklerini, görsel ve işitsel anlatım yöntemlerini nümerik sisteme dönüştürerek, geleneksel temsil sistemlerini veriler haline getirir. $\mathrm{Bu}$ anlamda, yeni medya verileri var olan görsel işitsel temsil geleneklerin nümerik hale getirilmiş halleridir.

5. Her Yeni Modern Medya ve İletişim Teknolojisinin Erken Dönemine Eşlik Eden Bir Estetik Olarak Yeni Medya - 'İdeolojik mecazlar düzenli olarak tekrar ortaya çıkarken birçok estetik strateji iki veya üç defa yeniden ortaya çıkabilir... Bu yaklaşımın gerçekte kullanışlı olabilmesi için stratejileri ve mecazları tanımlayıp ortaya çıkma anlarını kaydetmek yeterli değildir; bunun yerine teknolojinin tarihini modern dönemin sosyal, politik ve ekonomik tarihleri ile ilişkilendiren çok daha kapsamlı bir inceleme geliştirmek gerekir. Bu örneği 80'li yılların video sanatı kavramı içinde yeniden değerlendirmek mümkündür. Video dönemin yeni iletişim aracı olarak kendi estetik kullanım pratiklerini oluşturmuş olmakla birlikte, kendinden sonra ortaya çıkan diğer elektronik iletişim ortamları ile yeniden devşirilerek, var olan estetik pratiklerinin her dönemde yeniden dönüşmesine de vesile olmuştur.

6. Geçmişte Elde Veya Başka Teknolojilerce Yürütülen Algoritmaların Daha Hızlı Yürütülmeleri Olarak Yeni Medya - Bilgisayarlar, eskiden elde uygulanan tekniklerin çok büyük hızlandırmalarıdır, örneğin hesap makineleri gibi... 'Yürütmenin belirgin derecede hızlandırılması geçmişte var olmayan sunum tekniklerini mümkün kılar'. Bu aynı zamanda etkileşimli multimedya ve bilgisayar oyunları gibi birçok yeni medya sanatı biçimini de mümkün kılmaktadır. "Bir noktada modern bir sayısal bilgisayar aslında sadece hızlı bir hesap makinesidir".

7. Modernist Avant-Garde'ın Kodlanması olarak Yeni Medya; Metamedya Olarak Yeni Medya - Manovich, Yeni Medya açısından 1920'lerin diğer bütün zaman dilimlerine oranla daha ilgili olduğunu belirtmektedir. Her ikisinin de yeni işler yarat- 
mak yerine eski işleri yeniden işlemeleri açısından metamedya postmodernizm ile örtüşmektedir. Yeni medya avant-garde 'enformasyonun yeni şekillerde erişilmesi ve müdahale edilmesi hakkındadır' (ör. hipermedya, veri tabanları, arama motorları vs.). Meta-medya, yeni medya teknolojisinin ve müdahale tekniklerinin 'modernist estetikleri çok farklı postmodern estetiklere yeniden kodlayabilmesi' gibi miktarın kaliteye dönüşebilmesinin bir örneğidir.

Tüm bu tanımların yanısıra önem kazanan belirgin başlıklardan biri ise, erken dönem yeni medya araçlarından farklı olarak, gelişimini tamamlamış ve toplum tarafından kullanılmaları alışkanlık haline gelmiş yeni iletişim teknolojileri ile toplumu oluşturan bireylerin nasıl bir ilişki içinde olduğudur. Yeni medya ürünlerinin bireysel kullanımlarından doğan ortaklıklara bağlı olarak, yeni medya kullanım pratiklerinin nasıl yapılandığı diğer önemli bir araştırma alanıdır. Toplumu oluşturan bireylerin ortak kullanım alanları, yeni medyanın kamusal alandan nasıl kullanıldığı ya da bireysel iletişimi için yeni medyanın hangi biçimde kullanıldığı gibi sorular, yeni medyanın toplumsal boyutları ile ilişkilidir. Çünkü insanoğlu yeni medya dönemi öncesinde de toplumsallaşma sürecini yönetebilen, sürdürebilen bir varlıktır. Öte yandan yeni medyanın toplumları özellikle bilgisayar aracılığı ile iletişim süreçlerine yönlendirmesi ile birlikte, daha önce var olmayan, ya da en azından biçim değiştiren, yeniden yapılanan bir toplumsallaşma sürecine yönlendirdiği de açıktır. O halde, bilgisayar aracılığı ile toplumsallaşma nasıl bir sürece denk gelmektedir? Toplumsallaşmanın sayısal biçimleri nasıl ifade edilebilir?

$\mathrm{Bu}$ soruların yanıtlarını ararken öncelikle toplumsallaşmanın tanımını yeniden hatırlamak gerekir. Toplumsallaşmayı bireylerin bir toplum içinde yer alabilmek, toplumun bir parçası haline gelebilmek için ortaya koydukları tüm tutum ve davranış biçimleri olarak tanımlamak mümkündür.

\section{KAVRAM OLARAK TOPLUMSALLAŞMA}

"Toplumsallaşma" nın kavram olarak anlamı ise "bireyin kişilik kazanarak belli bir toplumsal çevreye hazırlanması, toplumla bütünleşmesi süreci, sosyalleşmesi" olarak tanımlanır. Bireyler bir toplum içinde doğdukları için, içinde doğdukları topluma adaptasyonu, bu toplum içinde yaşamını sürdürebilmek için kendine özgü bilgi ve beceriler kazanarak, toplumun bir parçası olabilmesi; toplumsallaşmayı tanımlayan tüm süreçlerdir. İşte bu süreçler, insanı biyolojik bir varlık olmaktan çıkarır ve toplumsal bir varlığa dönüştürür. Aynı zamanda bu süreç, bireylerin toplumsal değer ve normları öğrenmesi, içselleştirmesi, içinde bulunduğu toplumun bir parçası olabilmesi için, tüm insani ve toplumsal değerleri kazanabilmesini anlamina da gelir.

Toplumsallaşma sürecinde birey topluma ait değer ve normları sadece öğrenmez, aynı zamanda içselleştirir. İçinde bulunduğu toplumun genel norm davranış kalıpları hakkında fikir sahibi olur ve toplumun bir parçası olabilmek için gerekli davranış kalıpları hakkında fikir yürütmeye başlar. İşte bu nedenle bu 
süreç sadece bir öğrenme sürecine değil, aynı zamanda gerekli olan davranış kalıplarını içselleştirme ve bütünleşme sürecine karşılık gelir. Bu süreç toplum ve birey arasındaki kesintisiz bir etkileşim süreci ile süregider ve bireylerin ölümlerine dek devam eder. İnsanın doğumundan ölümüne kadar toplumsallaşan bir varlık olduğu savı da bu sürece dayanır. Toplumsallaşma bu nedenle yaşamın tüm evrelerini kapsar ve insan yaşadıkça bitmeyen bir süreç olarak devam eder.

\section{YENI MEDYA VE TOPLUMSALLAŞMA}

Toplumsallaşma kavramını sosyologlar iki farklı anabaşlık içinde ele alırlar ve bu anabaşlıklar birincil ve ikincil toplumsallaşma süreçleridir. Birincil toplumsallaşma; kişilerin çevresine ayak uydurmak için gereksinim duyduğu hayat ve dünya bilgisinin temellerinin atıldığ dönemdir. Bu süreçte kişilerin çevrelerindeki dünyaya ve topluma uyumunun esasları ortaya konur. Bireyin yaşamını sürdürebilmesi için, varlığını güvenli bir şekilde devam ettirebilmesi toplumla olan ilişkilerini düzenleme sürecini içerir. Bireyler kendilerine ve çevrelerine bu dönemde güven duymaya başlarlar. Bu nedenle birincil toplumsallaşma, anne karnında başlayan ve ileri çocukluk dönemine kadar süregelen bir dönem içinde ele alınır. Çocuğun toplum içinde edindiği farklı roller ve bu roller sayesinde geliştirdiği farklı davranış biçimleri birincil toplumsallaşma sürecine karşılık gelir. Hatta çocukların sadece kendi davranışlarını geliştirme süreçleri değil, karşısındaki kişi ya da gruplar ile olan ilişkilerinde beklentiler, beklentilerini karşılayabilme becerileri, geliştirdiği yeni davranış modelleri bu dönemde öne çıan önemli başlıklar arasındadır. Aile ve okul, bu dönemin en önemli kurumları arasındadır; çünkü çocuk ilk toplumsallaşma süreçlerini önce ailede, sonra da okulda yaşar.

Toplumsallaşma süreçlerinin bir diğer ana başlığı ise ikincil toplumsallaşma olarak tanımlanır ve bu kavram, bireylerin toplum içindeki yerlerinin pekişmesinde önemi olan kurumsal alt dünyaların özümsenmesine karşılık gelir. Özümsenmiş alt dünyalar ile bireyin ilişkisi tarafından yapılanır. Bireyin toplum içinde farklı roller altında geliştirdiği farklı davranış biçimleri, farklı kimliklerle toplum içinde yer alabilme özellikleri, farklı kişi ve gruplar ile olan ilişkilerini yönetebilme becerileri; ikincil toplumsallaşma süreçlerini içinde tanımlanır.

Bireylerin toplumsallaşmasına geleneksel medya ve yeni iletişim teknolojilerinin etkisi konusunda ise farklı görüşlerin öne sürüldüğü bilinmektedir. Örneğin, Elkind (2007), geleneksel medyanın ve özellikle televizyonun çocukların toplumsallaşmasında çok önemli bir role sahip olduğunu betimlerken, bu araçların tek yönlü yapısına vurguda bulunur. Wright (2001) ise, televizyonun etkileşimsiz yapısına rağmen, çocuklar ile sanki etkileşimliymiş gibi bir iletişime girdiğini belirtir. Çocuklara toplumsal özellikler yüklediği izlenimi verirken aslında toplumsallaşma sürecinde herhangi bir artı değer kazandırmadığını vurgular. Çocuklar televizyonla iletişim ihtiyaçlarını karşılarken, toplumsallaşma sonucunda edinebilecekleri becerileri kazanamamış olurlar. Çünkü toplumsallaşma ancak 
gerçek yaşamda var olduğu gibi, gerçek bir etkileşimli süreç içerisinde, gerçek durumlar karşısında farklı davranış biçimleri geliştirebilme süreçlerini içerir. Oysa, geleneksel medya bundan yoksun olarak, Baudrillar'ın (2013) deyimi ile etkileşimli olmayı ancak simüle edebilir.

Geleneksel medyaya karşın, yeni medyanın çocukların toplumsallaşma gereksinimlerini ne derece karşılayabileceği konusunda ise en çarpıcı örnek oyunlar üzerinden verilebilir. Belirli bir senaryo üzerinden geliştirilmiş ve siber bir karakter ile oynanan tüm oyunlarda, geleneksel medya ile olan iletişim süreçlerine benzer bir durumun yaşanacağı ileri sürülebilir. Çevrimdışı olarak oynanan bu oyunların kendi senaryo yapıları, oyun kuralları, siber karakterlerin oyuna katkısı daha önce kodlanmış olarak oyun içinde yer alır. Bu nedenle çocuk, bu oyunları oynarken, aslında var olan seçenekler sınırları içinde gezinir ve aynı davranış biçimleri karşılığında oyundan her zaman aynı tepkileri alır. Oysa gerçek yaşamda bir arkadaşla ile oynanan oyunda, gerçek bir insanın her durumda aynı tepkiyi vermesi beklenemez. Bu benzersiz tepkiler bütünü, beklenmedik iletişim süreçleri içinde kendi iletişim sürecini yapılandırma ve sürdürebilme becerileri, belirli kalıpları olan bir oyunun içinde gelişemez. Bu nedenle çocuklar için birincil toplumsallaşma süreçlerini yeni medya üzerinden geliştirmek, belirli kalıplar dışına çıkamamak ile eş anlamlı hale gelebilir. Oysa gerçek yaşam, belirli kalıplar içine sığmayan, her birey için farklı davranış özellikleri ile bezenmiş, çevrimiçi bir oyun içine sığdıramayacak kadar zengin davranış biçimleri içeren gerçek bir öğrenme sürecine karşılık gelir. Bu nedenle yüz yüze olmayan tüm iletişim modellerinin birincil toplumsallaşma süreçlerini sekteye uğratacağı, araç kullanarak toplumsallaşmanın gerçek anlamda sağlanamayacağı, sağlansa bile yüz yüze olan iletişim biçimlerinin yerini tutamayacağı yönündeki görüşleri göz ardı etmemek gerekir. Çevrimiçi olarak, sanal karakterler değil de, gerçek kullanıcılara karşın oynanan oyunlarda ise, yarı yapılandırılmış bir dünya içinde toplumsallaşıldığını ifade etmek olasıdır. Öyle ki, gerçek kullanıcılar, sanal karakterlerin standartlaştırılmış davranış biçimlerinin dışına çıkabilmekle birlikte, bunu oyunun karakteristik özellikleri dahilinde gerçekleştirebiliyor olmaları, oyun içinde yaşanabilecek toplumsallaşmanın yarı yapılandırılmış bir biçimde gerçekleşmesine yol açar. Gerçek karakterler farklı davranış biçimlerini ancak oyunun elverdiği sınırlar içinde gerçekleştirebilir. Oysa gerçek yaşamda birey ya da çocuk, anlık olarak oyun içindeki rolünü değiştirebilir, oyunun kurallarında değişikliğe gidebilir, farklı oyunlara kolaylıkla geçiş yapabilir. Gerçek dünyanın farklılıklara açık, eşitsizliklere izin veren yapısı içinde çocuk, tüm bu değişkenlere karşılık, kendi toplumsal rolünü yapılandırmada daha özgürdür.

Öte yandan, çocukların sokakta oynadıkları oyunların gözetimlerini yine oyunu oynayan çocukların kendileri yaparlar; bu nedenle çocuk ile bilgisayar değil, çocuk ile çocuk iletişime geçer ve bu nedenle bilgisayarla oynanan oyunlara karşın insan faktöründen kaynaklanan kural sapmaları yaşanabilir. Diğerlerinden daha büyük/güçlü/popüler/ sözü geçen herhangi bir çocuk anlık olarak kuralın uygu- 
lanmasına engel oluşturabilir. Oysa bilgisayar aracılı̆̆ı ile oynanan oyunların kuralları ve gözetimi bizzat yine bilgisayarlar tarafından gerçekleştirilir. Bu nedenle, bilgisayarlar tarafından yapılandırılmış kuralların herhangi bir nedenle değiştirilmesi söz konusu değildir. Bilgisayarlar tarafından yapılandırılmış oyunların kullanıcılarına daha adil ve daha steril bir ortamda toplumsallaşma olanağı sunduğu ileri sürülebilir; oysa yüz yüze gerçekleşen ve oyun temelli toplumsallaşma süreçlerinde zaman zaman kurallarda değişkenlikler yaşanabilir. Binark ve Bayraktutan Sütçü'ye (2007) göre sayısal oyunlar genç neslin toplumsallaşma süreçlerini doğrudan etkiler. Binark ve Bayraktutan Sütçü, bu yeni sayısal toplumsallaşma biçimi Bakardjieva'nın ifadesi ile hareketsiz toplumsallaşma olarak tanımlar. Livingstone ve Bevill (2000), medya aralığı ile gerçekleştirilen her toplumsallaşma sürecinin, gerçek toplumsallaşma süreçlerini simüle ettiğini, yeni medyanın ise, geleneksel medyaya karşın bir çok iletişim ortamını kendi içinde bulundurarak gençlere bir medya karışımı sunduğunu, herhangi bir araç ile gerçekleşen iletişim sürelerinin artmasının bir başka araç ile geçirilen zamanda azalmaya neden olmadığını, aksine araç kullanılmadan gerçekleştirilen toplumsallaşma sürelerinde kısalmaya neden olduğunu belirtirler. Bu durum, 2000'li yılların toplumsal yaşamında ekran bağımlı iletişim süreçlerinin bu derece baskın bir hal almasını açılamaya yardımcı olabilir. Ekran tabanlı iletişim süreçleri, sadece çocukların ya da gençlerin değil, yetişkinlerin de en çok tercih ettiği toplumsallaşma türleri arasındadır.

Diğer yandan, Manovich'in (2003) yeni medyayı tanımladığı sekiz başlığı yeniden hatırlamakta yarar vardır. Yeni medya birçok durumda var olan kültürel gelenekler ile yazılım geleneklerini bir araya getirme konusunda öncü rol oynar. Birçok oyun geliştiricisi aynı zamanda bu durumun oldukça farkındadır ve çocukların çoklu ve belirsiz davranış biçimleri arasında yer alabilecek oyunları tasarlamaya yönelmişlerdir. Bu nedenle, sadece çocukların değil, yetişkinlerin de oyun oynama alışkanlıkları beklentileri yeni oyun tasarımlarının geliştirilmesine katkıda bulanmaktadır.

\section{YENİ MEDYA VE İKINCIL TOPLUMSALLAŞMA}

Yeni medyanın toplumsallaşma sürecinde günümüz ağ toplum yapılanması içinde ne derece önem taşıdığını vurgulamak için, Giddens'ın toplumsal yapılanmanın oluşumunda yazının bulunuşuna verdiği önem örnek olarak gösterilebilir. Giddens (2012) sanayileşme ve küreselleşmenin kültürel etkenlerini sıralarken, değişimin nitelik ve yönünü etkileyen kültürel etkilerden biri olarak iletişim sistemlerinin yapısını gösterir. Yazının bulunmasını örnek göstererek, yazı kullanan toplumların geçmişlerinin kaydının tutulmasını, kendi kültür ve tarihlerinin oluşmasında ne derece önemli bir yere sahip olduğunu vurgular. Buna benzer bir ifade sayısal teknolojilerin toplumların kültürel yaşamını belirleyen bir etken olması üzerine de söylenebilir. Tıpkı yazının bulunması gibi, sayısal teknolojilerin gelişmesi ile birlikte sadece bireysel değil, toplumların kayıtları da sayısal veriler olarak arşivlenebilir, kültürel bir geçmiş, sayısal bir tarih oluşturacak 
şekilde kaydedilebilir ve saklanabilir. Bu kültür, Giddens'ın ifade ettiğinden farklı olarak sayısal bir kültürdür. Sayısal kültür sadece teknolojik anlamda değil, bu teknolojiyi kullanan toplumların toplumsallaşmasında ve kültürel dönüşümünde de farklılıklar gösterir. Nasıl geleneksel iletişim ortamları, resmetme teknikleri, farklı kayıt teknolojileri 2000'li yıllara kadar toplumların geleneklerinin oluşmasında bir kayıt işlevi görmüşse, sayısal teknolojiler ve kendine özgü medyalaştırma süreçleri de, kitlelere ait yeni sayısal toplumsallaşma biçimlerinin oluşturmasına aracı olur. Toplumsallaşma süreçlerinde geleneksel olarak kullanılan tüm tanımlar kendi varlıklarını sürdürseler de, bireylerin bir araya gelerek oluşturdukları kültürel değerler sisteminde kullandıkları araçlar farklılaşmış, McLuhan'ın bakış açsına dayandırılabilir bir ifade ile, sayısal teknolojiler bir araç olarak kültürel kodların oluşmasında kendine özgü bir yapılanmanın oluşmasına etkide bulunmuştur. Aracın, mesaja dönüştüğü bir ortamda, yeni medya kendine özgü bir toplumsallaşmanın ortaya çıkmasına önayak olmuştur. Bu etki, Giddens'ın (2012) yazının kullanılır olmasına yüklediği toplumsal rol, Brecht'in (1964) çift yönlü bir radyo sistemi gerçekleştiğinde yerine getirebileceği işlevsel özellikler gibi, 2000'li yılların ağ toplumunun toplumsallaşmasında oldukça belirgin dönüşümlere neden olabilecek kadar güçlüdür.

\section{AĞ TOPLUMUNUN YAPISI}

Kavram olarak ağ toplumu, Castells (2008) tarafından tanımlanmış, gündelik yaşamlarında geleneksel iletişim araçları yerine yeni medyayı kullanagelen, yeni medyanın iletişim olanaklarını gündelik yaşamı içine yerleştirmiş ve belirli bir alışkanlık edinmiş bir topluma karşılık gelmektedir. A $\breve{g}$ toplumu, Bell'in (1996) endüstrisi sonrası toplumunun toplumsal yapılanmasını ağ üzerinden gerçekleştiren biçimi olarak da tanımlanabilir. Bell, endüstri sonrası toplumu tanımlarken, bilginin üretilmesini ve bilginin dolaşımını ön plana çıkarırken, Castells'in ağ toplumunda toplumsal yapılanma süreçleri ve bilginin dolaşımı ağ üzerinden gerçekleşir. A $\breve{g}$ toplumu bu nedenle endüstriyel bir toplum olmaktan çok enformasyonel bir toplumdur. Toplumsal yapılanmasını da bilginin serbest dolaşımı üzerine yapılandırır. Tıpkı endüstri toplumunda üretilen endüstriyel ürünlerin serbest dolaşımında olduğu gibi, ağ toplumunda öne çıkan en önemli olgu, önemli ya da önemsiz, anlık ya da geçmiş, üretilen tüm bilgilerin paylaşılabilir, manipüle edilebilir olması önemlidir. Devletlerin özellikle teşvik ettiği enformasyona yönelik kalkınma biçimleri, toplumsal yapılanma tarafından da desteklenir. Güçlü bir ekonomi için sürdürülebilir bir yeni medya teknolojisi pazarı ve bu pazarı destekleyecek toplumsal alt yapı gereklidir.

2000'li yılların ağ toplumu bu sürecin tüm gereksinimlerini karşılayabilecek yapılanmasını gerçekleştirmiş, teknoloji ve toplum ilişkilerini hem toplumsal kullanım pratikleri, hem de ekonomik alt yapısı özellikleri ile çözmüş örgütlenme biçimleri gösterir. A $\breve{g}$ toplumu bu örgütlenme süreçlerini tamamlamış ve yeni medyaya ilişkin kendi geleneklerini oluşturmuş bir yapı içerir. Bu geleneklerin oluşmasında ve yerleşmesinde yeni iletişim ortamları belirleyici bir rol oynarlar; 
öte yandan yeni medya ortamları da, toplumun iletişim ihtiyaçları tarafından yeniden şekillenir. Teknoloji toplumu biçimlendirirken, toplum da teknolojinin gelişim süreçlerini belirler. Teknoloji ve toplumsal yapı arasındaki bu önlenemez ilişki, yeni medyanın toplumsal kullanım pratiklerinin her aşamasında kolaylıkla gözlemlenebilir. Teknoloji toplumsal yapıyı dönüştürürken, dönüşen toplumsal yapı da kendi teknolojisini üretir. Bu süreç karşılıklı bir etkileşim üzerinde genişleyen bir süreçtir. Van Dijk (2006: 156), bu durumu bir tarafta toplumun iletişim teknolojilerini desenlediği, diğer tarafta ise yeni medyanın toplumsal yapıyı dönüştürdüğü karşılıklı dönüşüm süreci olarak tanımlar. Zaten ağ toplumunun yapılanma süreci de aynı aşamalara karşılık gelmektedir.

A $\breve{g}$ toplumunu tanımlayan diğer bir özellik ise, değişen zaman ve mekan ilişkisidir. Van Dijk (2006), ağ toplumunun boyutları arasında değişen zaman ve mekan kavramlarını ilk sıralarda ele alır. Ağ toplumu ile birlikte iş zamanı ile serbest zaman arasındaki ayrımların ve sınırların gitgide ortadan kalkar. Ağ toplumu, evi işe, işi eve dönüştüren bir yaşam pratiğini benimsemiş, işin tanımlarının yeniden yapılması için bilinen tüm geleneksel çalışma yaşamı jargonlarını alt üst etmiş, iş zamanını serbest zamana, serbest zamanı ise iş zamanına dönüştürmüştür. 2000'li yılların ağ toplumunun oluşturduğu toplumsal yapı, ekonomik açıdan tüm kurumları içerecek şekilde organizasyonel dönüşümünü tamamlamış, bireylerin iş zamanları ile serbest zamanlarının tümünü kapsayacak şekilde ağ yapılandırmalarını şekillendirmiş bir görünüm sergilemektedir.

Ağ toplumu ile birlikte modern dünyanın göstergeleri arasında sayılan geleneksel medya iletişim gelenekleri gitgide yok olurken, yerini yeni medyanın geleneklerinin oluşumuna bırakmıştır. Yeni medya kendi geleneklerini, geleneksel medyanın geleneklerinin üzerine inşa eder. Var olan gelenekler ve kodlardan yararlanarak, kendine özgü iletişim biçimlerinin ve bu iletişim biçimlerinin örgütlediği toplumsal dönüşümün varlığını pekiştirmesine önayak olur. Bu gelenekler içinde hem kitle iletişim biçimlerindeki dönüşüm, hem de bireysel iletişim süreçlerindeki yenileşmeler vardır. Yeni toplumsal yapının oluşumunda önce bilgisayar aracılı iletişim süreçlerini kavrayabilme, daha sonra mobil iletişimi ve ağ kültürü içinde çevrimiçi bir kimlik oluşturabilme, gündelik yaşam pratikleri içinde iş ve serbest zaman dahilinde yeni iletişim teknolojilerini benimseyebilme ve işlevsel olarak gündelik yaşamın içinde dahil edebilme gibi farklı bilgi ve beceri süreçleri yer alır. Bireylerin ağ toplumu içinde yer alabilmeleri için, bu bilgi ve becerileri yaşamlarının bir parçası haline getirebilmeleri gerekmektedir.

Bu süreç o kadar kolay işleyen bir süreç değildir. Prensky (2001) İnternet, bilgisayarlar, cep telefonları ve benzerleri yeni kitle iletişim araçlarını kullanarak büyüyen nesli dijital yerliler olarak tanımlar. 80'li yılların sonlarında yaşanan sayısal devrimden sonra yetişen her bireyi dijital yerli olarak kabul etmek gerekir; ancak asıl sorun daha önce doğan nesillerdedir. Prensky sayısal devrimden önce doğan bu kişileri dijital göçmen olarak tanımlar ve bu kişiler Prensky'e göre bir dijital yerli gibi davranamayacaklardır. En iyi ihtimalle dijital yerli gibi davran- 
maya çalışırlar; ancak hiçbir zaman bir dijital yerlinin yerini tutamazlar. Bu nedenle ağ toplumuna tam olarak geçişin de, Prensky'nin ifadesine dayandırılarak dünyada yaşayan tüm insanların dijital yerlilerden oluştuğunda tamamlanabileceği ileri sürülebilir.

\section{SOSYAL AĞLAR VE TOPLUMSALLAŞMA}

Sosyal ağlar, ağ toplumunun yapılanmasında yeni iletişim teknolojilerinin toplumsallaşma için en yetkin olarak kullanıldığı öğelerin başında gelir. Bireylerin bireysel ve toplumsal iletişim ihtiyaçlarını karşılamak üzere kurulmuş olan bu yeni iletişim ortamları, paylaşım, ortak ilgi alanlarını keşfetme, yeni kişiler ile tanışma ve yeni ilişkiler kurabilme, var olan ilişkilerini ağ üzerinden sürdürebilme, gerektiğinde kişisel haberleşme ortamları oluşturabilme ve bu ortamların sürdürülebilirliğini sağlama, anlık bireylerarası iletişim ihtiyaçlarını karşılama gibi farklı işlevleri yerine getirebilme becerilerine sahiptir. Sosyal ağlar sayılan bu ve benzeri ihtiyaçların tamamını ya da bazılarını karşılayabilecek özellikler içerir. Sosyal ağlar güçlü yapıları ile bireylerin bir araya toplanabilecekleri, gruplar oluşturabilecekleri, çevrimiçi altyapıları hazırlayabilecekleri ve bu iletişim etkinliklerinin sürdürülebilirliğini destekleyebilecekleri bir yapı içinde tasarlanmıştır.

Sosyal ağları diğer iletişim ortamlarından ayıran en belirgin farklılıklarından biri, medya içeriğinin profesyoneller tarafından değil, bizzat kullanıcılar tarafından üretilmiş olmasıdır. Bu nedenle sosyal ağları bir paylaşım ortamı, bireysel bir iletişim aracı, bir eğlence merkezi, bir kitle iletişim aracı, bir haber kaynağı, bir sanal cemaat ve bir eğitim ortamı olarak ele almak mümkündür. Sosyal ağların oluşturduğu kullanıcı içeriği, bu ağların geleneksel medyadan farklı, kendilerine özgü, tamamen kullanıcı içeriklerinin oluşturduğu bir yeni medya akışının ortaya çıkmasına yol açmıştır. Yeni medya akışı, kendi karakteristik özellikleri ile, geleneksel medya akışından bütünüyle farklıdır (Cemiloğlu Altunay 2010). Sosyal ağlar kullanıcısına sadece etkileşimli bir iletişim ortamı sunmaz, bunun yanında medya içeriğinin kullanıcılar tarafından üretildiği bir ağ ortamı da oluşturur. Kullanıcılar oluşturdukları içerikleri kendi grupları içinde paylaşabilir, dilediklerinde silebilir, gizleyebilir, farklı içerikler ile ilişkilendirebilirler ve bunu yaparken de her kullanıcı kendi kişiselleştirdiği olanaklar doğrultusunda gerçekleştirir. Sosyal ağların bu özgürlükçü ve farklılıklara izin veren yapısı, 2000'li yılların en çok zaman harcanan iletişim ortamları haline sokmuştur. Günümüz sosyal ağları, gündelik yaşamın önemli bir parçası haline gelmiş, bireylerin toplumsallaşma süreçlerini yapılandırdığı en temel çevrimiçi ortamlardan birine dönüşmüştür.

Sosyal ağları bir kullanıcı içeriği aracın dönüştüren temel yapısal devrim web 2.0 teknolojisinin geliştirilmesi ile başlar. Sosyal ağların tarihi, bir İnternet teknolojisi olarak web 2.0 tarihi ile eşdeğer olarak gelişmiştir. Sosyal ağlar web tabanlı olarak çalışırlar ve teknolojik alt yapıları yine bu teknolojinin uygulamalarına daya- 
nır. Web 2.0, kavramı ikinci nesil İnternet hizmetlerini - toplumsal iletişim sitelerini, wikileri, iletişim araçlarını- bir başka ifade ile İnternet kullanıcılarının ortaklaşa ve paylaşarak yarattığ sistemi tanımlar (O'Reilly 2005). Bilinen en eski sosyal ağ SixDegrees'dir ve 1997 yılında kurulmuştur (Toprak ve ark. 2009); ancak daha sonra gerçekleştirilen birçok sosyal ağ denemesi başarısızlıkla sonuçlanmıştır. Sosyal ağların temel işleyiş prensibi insanlara dayanır. Öte yandan birçok insanı aynı platformda toplayacak bir sosyal ağ tasarlayabilmek de her zaman oldukça zor olmuştur. SizDegrees'ten sonra Facebook ve Twitter gibi küresel sosyal ağların toplumun her kesimini kapsayacak bir yapıya ulaşması sürecinde birçok sosyal ağ denemesi bu nedenle hayal kırıklığı ile sonuçlanmıştır. Sosyal ağların başarılı olabilmeleri için bireyleri cezbedici içerikleri sağlayacak ortamları oluşturabilmesi, bu içeriği saklayabilecek ve işleyebilecek teknolojik altyapıya da sahip olabilmeleri gerekir.

2000'li yılların başarılı sosyal ağları dikkate alındığında iki önemli özelliği dikkat çeker. Bunlardan ilki, ağların teknolojik altyapısı ile ilişkilidir. Günümüzün başarılı sosyal ağları için kullanıcılarının ihtiyaçlarını karşılayabileceği teknik alt yapı olmazsa olmaz bir özelliktir. Kullanıcılar oluşturdukları içerikleri herhangi bir teknik sorun yaşamadan saklayabilmeli, kendi içeriklerini sorunsuzca oluşturabilmeli ve bu içeriklere her an, her yerde, farklı teknolojileri kullanarak ulaşabilmelidir. Bu nedenle teknolojik altyapı sosyal ağlar için olmazsa olmaz bir şart gibidir. Sosyal ağlar için bu teknolojik güvenilirlik ve sürdürülebilir iletişim süreçleri en temel gereksinimlerden biridir. Günümüzün başarılı sosyal ağların temelinde kullanıcıları için kolay işletilebilir ve ulaşılabilir altyapıları yatmaktadir.

Taşçı (2010), sosyal ağları veya Web 2.0'ın kapsadığı tüm alt kümeleri aşağıdaki şekilde sıralamamıştır:

- Bloglar

- Mikrobloglar

- Sosyal ağlar

- Açık kaynak ansiklopediler

- Sosyal bookmarking

- Sosyal haber

- Fotoğraf paylaşımı

- Video paylaşımı

- $\quad$ Ses ve müzik paylaşımı

- Anlık mesajlaşma uygulamaları

- Forumlar

- Sanal oyunlar

- Sanal cemaatler

Sosyal ağlar, kişilerin bireysel özelliklerine göre kendi profillerini oluşturabildikleri, oluşturdukları profiller ile kendi bireysel ilişkilerini sürdürebildikleri, aynı 
zamanda hem bir birey, hem de bir grup üyesi olarak iletişimlerini yapılandırabildikleri; hem bireysel, hem de kitlesel iletişim ortamlarını kullanıcılarına sağlarlar. Sosyal ağların bu derece yetkin kullanım alanı olması, 2000'li yılların en etkin iletişim ortamlarının sosyal ağlar olmasına yol açmıştır. Türkiye, bu açıdan bakıldığında sosyal ağları en çok kullanan ülkelerin başında gelir. Facebook kullanan ülkeler dikkate alındığında Türkiye' den üye olanların sayısı dünyada ilk 3 arasında yer alır. Türkiye ve diğer ülkelerde sosyal ağların bu derece yoğun bir kullanım alanına sahip olmasını; sosyal ağların kullanıcı içeriğinden oluşması ile açıklanabilir. Bu kullanıcı içeriklerini bireyler kendi taleplerine göre biçimlendirebilir ve kişiselleştirebilir. Sosyal ağların karakteristiklerine göre kullanıcılar kendi kullanım pratiklerini geliştirebilir ve kullanıcılar sosyal ağları diledikleri zaman bir kamusal alana, diledikleri zaman ise bir özel alana dönüştürebilirler. Van Dijk (2006) bu durumu ağ toplumunun yapısal özelliği olarak tanımlar. A $\breve{g}$ toplumunda özel alan ile kamusal alanın sınırları gitgide bulanıklaşır.

Sosyal ağların toplumsallaşma konusundaki bir başka özelliği ise kişiselleştirilebilir olmasında yatar. Kişiselleştirilebilen ağlar ile birlikte her kullanıcı kendine özgü iletişim ortamını yaratabilme, kendine özgü iletişim pratiklerini geliştirebilme şansını elde eder. Bu durum ise, bireylerin iletişim ortamlarını kendi ihtiyaçları doğrultusunda şekillendirebilmesi anlamına gelir. İşte bu özellik, ağ toplumunu geleneksel medyaya özgü toplumsal yapılanmadan çok daha farklı bir yöne doğru götürür.

Öte yandan gündelik kullanım pratikleri ve yeni medyanın dayandığı teknolojik alt yapı arasındaki ilişki göz önüne alındığında, sosyal ağların en önemli karakteristiklerinden birinin, bir araç olarak sosyal ağların aynı zamanda hem bir bireysel iletişim aracı, hem de bir kitle iletişim ortamı haline dönüşebilmesi olduğu ileri sürülebilir. Öyle ki, sosyal ağlar her iki iletişim sürecini de aynı anda yönetebilme ve yürütebilme potansiyeli sahip ortamlar olmakla beraber, bu ayrımın dayandığı temel noktanın işin teknolojik altyapısından çok, yeni medya ortamlarının kullanım pratiklerinde yattığı söylenebilir. Örneğin, herhangi bir kişi ile yapılan bir görüşme içeriği kolaylıkla farklı kişiler tarafından birebir kopyalanarak, yine farklı kişilere anında aktarılabilir ve birebir iletişim sürecine ait olan bir ileti, hiç beklenmedik bir anda kitlelere ulaşabilen bir kitle iletişim iletisi halini alabilir. Bu hılı dönüşümün temelinde sadece aracın bu süreci yönetebilme kapasitesi değil, aynı zamanda bireylerin bu aracı kullanma alışkanlıkları ve bu alışkanlıklara bağlı olarak ortaya çıkan yeni medya kullanım gelenekleri vardır. Toprak ve arkadaşları (2009) Facebook üzerinde yaptıkları araştırma sürecinde, sosyal ağların kullanıcılar tarafından tercih edilme nedenlerini aşağıdaki gibi sıralamışlardır:

- Arkadaş bulmak amaçlı

- Denetim ve gözetim amaçlı

- Video, fotoğraf, müzik, fikir paylaşımı amaçlı

- Oyun amaçli 
- Örgütlenme amaçlı

- Siyasal amaçlı

- E-ticaret amaçl1

- Cinsel amaçlı

- İhbar amaçlı

Sosyal ağları diğer toplumsallaşma araçlarından ayıran temel özelliklerden biri de bireylerin kendi talepleri doğrultusunda kendi profillerini oluşturabilmeleri, tüm iletişim süreçlerini bu profil üzerinden gerçekleştirebilmeleri ve dilediklerinde bu profilleri anonim kimlikler olarak belirleyebilmeleridir. Anonim kimlikler, kullanıcıların gerçek kimliklerini gizleyerek sanal ortamda oluşturdukları gerçek dişı tüm kimliklere verilen addır. Anonim kimlikler gerçekte var olan başka karakterlerden oluşabileceği gibi, hiçbir zaman gerçek olmamış kimliklerden de oluşabilir. Sosyal ağların anonim kimliklere izin veren yapısı, birçok kişi için daha özgür bir iletişim ortamı sunar. Gerçek kimlikleri ile konuşamayacağı birçok şeyi kullanıcılar anonim kimlikler üzerinden konuşabilir. Bu nedenle anonim kimlik, konuşulamayanı konuşulur, söylenemeyeni söylenir kılar. Yeni medyanın anonim kimliğe izin veren yapısı, bireylerin yeni medyada kendi gerçek kimlikleri ile değil, sahte düzmece kimliklerle de yer alabilmelerini sağlar. Bireyler anonim kimlikler sayesinde gerçek hayatta ortaya koyamayacakları iletişim süreçlerini yeni medya aracılığı ile yaşarlar.

Sosyal ağlar, gerçek yaşamlarında herhangi bir toplumsal gruba üye olamayan bireyleri, kolaylıkla bir grubun üyesi haline getirir. Bireylerin kendi talepleri ve görüşleri doğrultusunda sanal cemaatler oluşturabilmelerini sağlar, bu süreçteki zaman ve mekan sınırlılıklarını ortadan kaldırır. Bu grup içinde ye alan bireyler ile eşzamanlı ya da eşzamansız olarak iletişebilmelerine, bu grup üzerinden toplumsallaşabilmelerine ortam oluşturur. A $\breve{g}$ cemaatleri, toplumsal yapı içinde ağ örgütlenmesinin önemini arttırır. Daha önce var olmayan bir örgütlenme biçimi ortaya çıkarır. Soysal ağlar içinde yer alan herkes, ağın tüm özelliklerini kullanma ya da kullanmama da eşit ve özgürdür. Sosyal ağlar her kullanıcıya aynı mesafede durur ya da eşit şekilde yaklaşır. Bir kullanıcının diğerinden üstünlüğü yoktur. Bir fakülte dekanı ile, o okuldaki müstahdemin 12 yaşındaki çocuğu aynı platformda rahatlıkla buluşabilir ve bu buluşma kesinlikle her iki taraf içinde tamamen eşit koşullarda gerçekleşir. 12 yaşındaki çocuk, fakülte dekanının oldukça ciddi olarak tasarladığı bir iletisini kendi bakış açısı ile yorumlayabilir, paylaşabilir ve hatta engelleyebilir. Yazılım karşısında, kişiler arasındaki yaş, cinsiyet, eğitim vb. hiçbir farklılıklar, birini diğerinden daha ayrıcalıklı yapmaz. Yazılım için her kişi bir veridir ve her veri eşittir.

Diğer yandan sosyal medyanın bir yazılım ürünü olması ve bu yazılım karşısında herkese eşitlikçi olarak yaklaşması, sosyal medyanın kendi sınıf sistemini oluşturmadığı anlamına gelmez. Sosyal medya kendine özgü sınıf sistemini iki şekilde oluşturur. Bunlardan ilki, kullanıcıların sosyal medyaya ulaşabildikleri iletişim araçlarının ifşası, diğeri ise kullanıcıların çevrimiçi özelliklerinin ifşasıdır. 
Günümüzde bir çok sosyal ağ, kullanıcılar tarafından girilen bilgilerin hangi tür bir iletişim ortamı kullanılarak iletildiğini tüm kullanıcılarına gösterir. Bu durum kullanıcılar arasında ilk sınıf ayrımının oluşması anlamına gelir. Tümleşik cihaz ile bağlanabilen, sabit bilgisayarlara ihtiyaç duymadan içerik oluşturabilen kişiler, mekan bağımsız oldukları için kendilerini diğerlerinden farklı konumlandırabilirler. Aynı şekilde sosyal ağa sabit bir bilgisayardan bağlanan kişiler ile, mobil cihazlardan bağlananlar arasında da bir sınıf farkı oluşur. Tümleşik mobil cihazlardan içerik üretebilen kişiler zaman ve mekan bağımsız olarak çevrimiçi olanaklarına sahip olabildiklerinden, sosyal ağlar ile ilişkileri sadece bilgisayarlarının olduğu oda ile sınırlı değildir. Günümüzün birçok GSM şirketinin toplumsal statü sembolü olarak zaman mekan sınırsız çevrimiçi olabilecek ürünleri pazarlamaya gayret etmeleri ve reklam paylarının büyük bir bölümünü bireyleri mobil çevrimiçi ürünlere ayırmaları, bu durumu destekler niteliktedir. Teknoloji her zaman bir toplumsal statü sembolü olmuştur; ancak bu kez sadece bir sembol olmaktan çıkıp, bizzat ağ toplumunun sınıf yapısının oluşmasında bizzat rol oynayan temel etenlerden birine dönüşmesi tesadüf değildir. Günümüz iletişim etkinlikleri dikkate alındığında, sosyal ağlar üzerinden gerçekleştirilen anlık mesajlaşma, haber alma, öğrenme, paylaşma, kamuoyu yaratma, tepki oluşturma gibi etkinliklere sağladığı olanaklardan dolayı sosyal ağların gelecek yüzyılın en önemli iletişim ortamları haline geleceği ve en büyük teknolojik yatırımları ise bu ağlar üzerine desenlenmiş yeni medya ürünlerinin olacağı kolaylıkla tahmin edilebilir bir süreçtir.

\section{SONUÇ}

2000'li yılların ağ toplumun toplumsallaşma süreci, modern dünyanın geleneksel medyasının ortaya çıkardığı toplumsallaşma yapısından önemli farklılıklar içermektedir. Castells (2008) ve Van Dijk'ın (2006) ağ toplumu olarak adlandırdığı bu toplum örgütlenmesinde bireylerin öncelikle bilgisayar aracılı iletişim süreçlerini kavrayabilmesi, mobil iletişim süreçlerini gündelik yaşamının bir parçası haline getirebilmesi, ağ kültürünü özümseyerek kendi kültürel değerleri içinde konumlandırabilmesi gerekir. Prensky'nin (2001) dijital yerliler olarak tanımladığı, sayısal devrimden sonra doğan nesil, bu becerileri hâlihazırda kazanarak yetişe geldiklerinden, 2000'li yılların ağ toplumunda, toplumsallaşma geleneklerini de bu nesil belirleyecektir.

Yeni medyanın kendi toplumsal yapılanmasının yanında, 2000'li yılların toplumsallaşma ortamlarından biri de sosyal ağlardır. Sosyal ağlar, var olan toplumsallaşma geleneklerinin yanında, kendine özgü toplumsallaşma geleneklerinin de oluşmasını sağlarlar. Ağ üzerinden toplumsallaşma biçimlerinin, geleneksel toplumsallaşma süreçlerine göre kendine özgü karakteristiği bulunmaktadır. Bu karakteristiğin ilk özelliği, zaman mekan sınırsız iletişim biçimleri, zaman mekan sınırsız sosyalleşme süreçleridir. İkinci özelliği ise, kullanıcı içeriğine dayalı yapısı ile, profesyonel içerikten çok, amatör içerikler üzerine yapılandırılmış ilişki- 
ler yumağıdır. Sosyal ağların karakteristiğinde yer alan bir diğer özellik ise, kullanıcılarına anonim kimlikler üzerinden toplumsallaşabilme olanağını tanımasıdır. Böylelikle sosyal ağlar, geleneksel medya içinde yer alamayacak konuların konuşulmasına, söylenmedik sözlerin söylenebilmesine olanak tanır. Anonim kimlikler, toplumsallaşma süreçlerindeki değer yargıları, toplumsal kontrol mekanizmaları ve diğer denetim mekanizmaları içinde yer bulamayacak kişi ve konulara toplumsallaşma şansı tanır. Sosyal medyanın toplumsallaşma süreçlerinde bir artı değer olarak kullanıcılarına sunduğu bir diğer öğe ise, iletişim ortamları olarak sosyal ağların kullanıcıların talep ve tercihlerine göre kişiselleştirilebilmesidir. Yine bu özellik de geleneksel medyanın toplumsallaşma sürecinde kullanıcılarına sağlayamayacağı olanaklardan biridir. McLuhan'nın (2005) aracın mesajın içeriğini nasıl yeniden yapılandırdığı savı dikkate alındığında, ağ toplumunun şekillenmesinde iletişim ortamının kullanıcılar tarafından kişiselleştirebilmesinin önemi daha kolay anlaşılabilir. Sadece sosyal ağların değil, yeni medyanın kullanıcilarına sunduğu bir başka olanak ise sanal cemaatlerdir. 2000'li yılların ağ toplumu üyeleri bir grubun üyesi olmak, bir grup içinde yer almak, kendisini bir grup içinde ifade etmek için belirli topluluklar içinde fiziksel olarak yer almak zorunda değildir. A $\breve{g}$ toplumunun bireyleri toplumsallaşma gereksinimlerini evlerinden çıkmadan, ă̆ iletişiminin olanaklarını kullanarak ekranlarında oluşan temsil sistemleri dahilinde çözebilmekte, diledikleri gruplar içinde zahmetsizce yer alabilmektedirler. Sosyal ağların kullanıcılarına sağladıkları eşitlikçi olanaklarına karşın, toplumsal sınıf yapılanmasında katkısının olmadığ1 ya da sınıf sisteminin oluşmasına olanak tanımadığ1 düşünülebilir. Oysa, yaptıkları güncellemeler ile, sosyal ağ yazılımları kullanıcılarının iletişim sürecinde kullandıkları iletişim araçlarını ve ağa ulaşma biçimlerini sürekli ifşaa etmektedir. $\mathrm{Bu}$ ise kullanıcıların ellerindeki iletişim ortamları üzerinden belirli bir sınıflandırmanın yapılandırılmasına yol açar. Bir iletinin, sabit bir bilgisayardan ya da bir tabletten paylaşıldığının bilgisi, basit, masum ve anlamsız bir bilgi paylaşımı değildir. Bu bilgi paylaşımı, ağ toplumunun yeni sosyal sınıflarının oluşumu için bir ipucu niteliğindedir.

\section{KAYNAKÇA}

Alemdar K ve Erdoğan İ (2005) Öteki Kuram. Erk Yayınları, Ankara.

Altunay A (2013) Çağımızın Görsel İletişim Ortamı Olarak Yeni Medya, Hareketli Görüntünün Tarihi, Anadolu Üniversitesi Yayınları, Eskişehir.

Baudrillard J (2013) Similarklar ve Simülasyon. Oğuz Adanır (çev), Doğu Batı Yayınları, Ankara.

Bell D (1996) The Cultural Contradictions Of Capitalism, Basic Books, New York. Beville H (1948) The Challenge of the New Media: Television, FM, and Facsimile, Journalism Quarterly. Vol. 25, 3-11. 
Binark M (2007) Yeni Medya Çalışmaları. M Binark (der), Dipnot Yayınları, Ankara.

Brecht B (1964) The Radio as an Apparatus of Communication, Brecht on Theatre: The Development of an Aesthetic, John Willet (ed), Hill and Wang.

Cemiloğlu Altunay M (2010) Gündelik Yaşam ve Sosyal Paylaşım Ağları: Twitter ya da - Pıt Pıt Net, İletişim Dergisi, Galatasaray Üniversitesi Yayınları, Sayı 12, $31-56$.

Castells M (2008) A $\breve{g}$ Toplumunun Yükselişi, Ebru Kılıç (çev), Bilgi Üniversitesi Yayınları, İstanbul.

Elkind D (2007) The Power of Play: Learning What Comes Naturally, DeCopa Life Long Book, Berkeley.

Giddens A (2012) Sosyoloji, Kırmızı Yayınları, İstanbul.

Gitelman L and Pingree G B (2003) New Media, 1740-1915. MIT Press, London.

Livingstone S and Bovill M (2000) Young People, New Media, Media Culture Online, London.

http://mo2.lmz.navdev.de/fileadmin/bibliothek/livingstone_young_people/living stone_young_people.pdf erişim tarihi: 06-03-2015

McLuhan M (2005) Yaradanımız Medya, Ünsal Oskay (çev), Turkuvaz Kitap, İstanbul.

Manovich L (2002) The Language Of New Media, MIT Press, London

Manovich L (2003) New Media from Borges to HTML, New Media Reader, MIT Press, London.

Marvin C (1988) When Old Technologies Were New: Thinking About Electric Communication in the Late Nineteenth Century, Oxford University Press, New York.

O'Reilly T (2005) "What Is Web 2.0". O'Reilly Network, http://oreilly.com/ web2/archive/what-is-web-20.html, erişim tarihi: 06-03-2015

Pavlik J and McIntosh S (2004) Converging Media: An Introduction to Mass Communication. Pearson Books, Boston.

Prensky, M (2001) Digital Natives, Digital Immigrants. On the Horizon 9(5): 1-6. http://www.marcprensky.com/writing/Prensky\%20\%20Digital\%20Natives,\%20D igital\%20Immigrants\%20-\%20Part1.pdf, erişim tarihi: 06-03-2015.

Taşçı E (2010) Sosyal Medya Araçlarının Yerel Yönetimlere Etkisi ve Katkısı: Belediye 2.0, Türkiye Bilişim Derneği Bilişim Dergisi, Yıl: 38, Sayı: 126, s. 23-26. 
Selçuk İletişim, 2015, 9 (1): 410-428

Toprak A, Yıldırım A, Aygül E, Binark M, Börekçi S ve Çomu T (2009) Toplumsal Paylaşım Ağı Facebook: Görüyorum Öyleyse Varım, Kalkedon Yayınları, İstanbul.

Van Dijk J (2006) The Network Society, Van Dijk J (ed), Sage Publications, London.

Wright J C, Aletha C H, Kimberlee C M, Michelle St. P, Marites P, Ronda S and Jennifer K (2001) The Relations of Early Television Viewing to School Readiness and Vocabulary of Children From Low-income Families: The Early Window Project, Child Development, 72(5), 1347-1366. 